\title{
An Analysis of the Insurance Market in the Czech Republic
}

\author{
Liběna Černohorská ${ }^{1, *}$, Matěj Klofát ${ }^{1}$ \\ ${ }^{1}$ University of Pardubice, Faculty of Economics and Administration, Institute of Economic Sciences, \\ Studentská 95, 53210 Pardubice, Czech Republic
}

\begin{abstract}
.
Research background: We are currently witnessing significant changes in traditional values and developments concerning the globalization of the financial markets. Since the beginning of the 21 st century, not only have the instruments used by global financial markets changed significantly, but the way they operate and the behavior of their participants have changed as well. Digitalization and the use of modern technologies are gradually beginning to take hold in all segments of the global economy. In the field of insurance, this mainly concerns the areas of insurance distribution and claims settlement.

Purpose of the article: The purpose of this paper is to analyze the insurance industry in the Czech Republic for the period of 2014 to 2018.

Methods: Spider analysis was used to conduct the analysis. This type of analysis is a comprehensive analytical tool, which can also be used by the management of commercial insurance companies; it is based on 16 ratios, which are divided into four segments. Spider analysis provides a clear representation of the examined company's position in comparison with the market average or with competing companies in that field of business. Using spider analysis, it is possible to portray the insurance market in the Czech Republic using the selected insurance companies.

Findings \& value added: Based on the analysis results, it was found that Pojišt'ovna VZP was the only company that differed from the other commercial insurance companies analyzed - and the insurance market as a whole. Globalization's effects on developmental trends in the world's economies, the financial markets, and the business activities of both commercial insurance companies and the insurance industry are significant and difficult to estimate in terms of scope.
\end{abstract}

Keywords: financial market; insurance; insurance company; spider analysis

JEL Classification: F62; F65; G22; O16

* Corresponding author: libena.cernohorska@upce.cz 


\section{Introduction}

The insurance industry is a specific subset of the financial market and comprises its own sector of the economy. It is a tool used for providing financial compensation in the face of negative consequences from accidental events. If a party cannot avoid risk, they can use insurance to provide compensation for the potential amount of the damage. Around the world, there is the pervasive trend of globalization, unavoidable even by the insurance industry. Therefore, the impact of globalization, whether negative or positive, influences developments on the insurance market.

The world has been seeing consolidation and integration both at the government and individual company levels. We have therefore been witness to a decreasing number of insurance institutions on account of necessary merging and acquisition, which is the result of increasing competition. Attempts by individual countries to achieve ever greater transparency are accompanied by stronger international competition between individual insurers. These develop new products in the field of finance for use as additional tools to cover risk, and this increases competition in the financial sphere overall, not only between insurance companies. The growth of emerging market economies, eliminating the barriers between countries, and monetary system reform all affect insurance institutions as they enter international markets. As [1] and [2] mention, globalization has a positive influence on the development of life and non-life insurance.

Commercial insurance companies are economic entities that bear the risks resulting from their activities; long-term prosperity is exceptionally important for them, just as it is for other companies. Consequently, the ability to react to developments on the insurance market quickly and effectively and the capacity to adapt both to these as well as to client demand for their products factor into an insurance carrier's success. Insurance company management must know how the insurance market is performing, but it is more important to have a detailed perspective on the financial health of its companies.

Measuring company performance is a prerequisite for successful company management, regardless of the field of business. The insurance industry is a unique economic field, something that even shows up in the area of financial analysis. Certain financial indicators that can be commonly used for other economic entities do not have predictive value for commercial insurance companies. Numerous specially modified ratios are used to meet the needs of financial analysis of commercial insurers.

The goal of this paper is to analyze the trajectory of the Czech Republic's insurance industry and to compare it with selected insurance companies for 2014 to 2018 using spider analysis. Spider analysis provides a clear representation of a company's position in comparison to the market average or of competing companies in their field of business. With spider analysis, it is possible to depict the insurance market in the Czech Republic using the selected insurance companies.

\section{Literature Review}

There is no set opinion when it comes to the history globalization. For example, [1] links its emergence to the discovery of America and navigation around Africa between 1492 and 1498. On the other hand, [3] ties globalization's start to the period after World War II, because the end of the war coincided with the foundation of international institutions such as the International Monetary Fund and the World Bank. However, many other academics allege that it's beginnings arose in recent history [4], [5]. As is mentioned in [6], links the start of globalization to the beginning of the 1990s and also asserts that it was triggered by the end of the Cold War and expanded use of the internet. Since the time when globalization emerged as a worldwide trend, numerous studies have tried to determine whether it benefits financial 
and economic outcomes. Many studies have provided a theoretical perspective on the relationship between globalization and insurance market activities. Lower communication costs and reduced costs for storing and evaluating information have had a strong influence on the global insurance market [7]. The study [1] and [8] state that as markets continue to transcend borders, the regulation of national financial markets keeps expanding from one place of jurisdiction to another, which increases the risk of contradictory regulations and results in high costs for following these regulations. These authors further contend that new regulatory approaches are necessary at the supranational and global levels. Another study [9] demonstrates that even though there is significant heterogeneity between nationalities and regions influencing the insurance market, it holds that important global trends impacting the insurance sector are growing; examples of these are globalization, risk diversification via hedging, the emergence of substantial financial intermediaries, and the increasing importance of supranational agencies. The study [10] states that integration processes such as globalization, consolidation, and convergence are some of the trends influencing the insurance sector, and they will determine its success over the next decade.

The year 1948 represents a critical moment in the modern history of the Czech insurance market. This year saw the monopolization of the insurance market, which was marked by consolidating the five insurance companies existing at that time into one, Československá pojišt'ovna n.p. Czechoslovakia's federalization in 1969 caused the emergence of the České státní pojišstovna (the Czech National Insurance Company), which maintained its monopoly for over 20 years. In 1991, a law concerning the insurance industry was adopted; it was an important milestone for the emergence of the insurance industry in the Czech Republic as it demonopolized the insurance market and reestablished a competitive environment. The enacted law resulted in increasing the number of insurers on the Czech insurance market. The study [11] go into more detail about the legislative organization of the Czech insurance industry.

Digitalization and the use of modern technology have gradually been gaining ground in all segments of the economy. In the field of insurance, this primarily concerns the section of insurance distribution and claim settlement. The human factor has been replaced by modern systems, which can be seen in the insurance field's constantly decreasing number of employees. In 2014, Czech commercial insurance companies had over 13,000 workers; in 2018 , it was already less than 12,000 . In five years, the number of insurance workers dropped by more than $9 \%$, with most of these leaving within the last two years. As to this current trend, it can be expected that the number of employees in the field of insurance will continue to decrease. In addition to digitalization, another cause of workers leaving these financial institutions is that the government has placed stricter requirements on the levels of expertise needed by insurance intermediaries.

\section{Data and Methods Used}

As entities providing protection against unexpected events, commercial insurance companies collect money from the insured for the services provided in the form of insurance premiums. If all the responsibilities listed in the insurance contract and the relevant insurance conditions are met, the client will then have recourse to paymant claims. The main reason for conducting financial analysis on commercial insurance companies is to determine whether a given entity is able to fulfill the financial responsibilities resulting from the activities they have engaged in. Financial analysis ratios are generally applied without regard to a company's field of business; consequently, they can be used to determine the current financial situation of commercial insurers. As indicate [9], [12] and [13] in addition to these ratios, there are also ratios that have been specially modified for commercial insurance companies. 
In order to achieve this paper's set goal, it is necessary to analyze the Czech insurance market and conduct a comparison of select market entities for the years 2014 to 2018, specifically Pojišt'ovna VZP (a state-run company), Hasičská vzájemná pojišstovna (HPV), and Kooperativa pojišt'ovna. The selected insurance companies stand for individual representative entities on the Czech insurance market. The same as Pojištovna VZP, Hasičská vzájemná pojišt’ovna offers insurance products for individuals as well as businesses. Hasičská vzájemná pojišt’ovna's offering is composed of more than property insurance, indemnity insurance, travel insurance, vehicle insurance, and comprehensive coverage. In contrast to Pojišt'ovna VZP, its offering is not only limited to non-life insurance products. Clients with Hasičská vzájemná pojišstovna can also arrange for life insurance. Additionally, one of the strongest entities on the Czech insurance market was selected, Kooperativa pojišstovna, a.s., Vienna Insurance Group, which is the second largest insurer in the Czech Republic, with nearly $20 \%$ market share. The data for analysis was obtained from [14].

\subsection{Spider analysis}

The ratios used in financial analysis help analysts determine a return on equity, the accounts receivable turnover period, and a company's overall debt, among other things. The individual ratios' calculated values; however, do not indicate anything about whether a company's debt is low or too high - or whether the return on equity is good or not. Spider analysis is one of the approaches used to evaluate these readings of company performance. Depicting the results graphically contributes a clear rendition of the examined companies' position in comparison with competitive companies' market average in that field of business. Analysts use spider graphs to monitor the areas in which a company is stronger than its competitors, in which it lags behind them, and where the market average is holding. Spider analysis's indisputable advantage is its clear graphic layout. Their graphics have been identified as a useful technique for a wider group of users, which can include investors and other market participants. Generally, spider analysis uses 16 ratios, which are divided into 4 groups [15]. For the needs of our spider analysis model, the following modification of the classic spider graph has been applied to commercial insurance companies (Table 1).

Table 1. Spider Analysis Quadrants in the Graph of Commercial Insurers

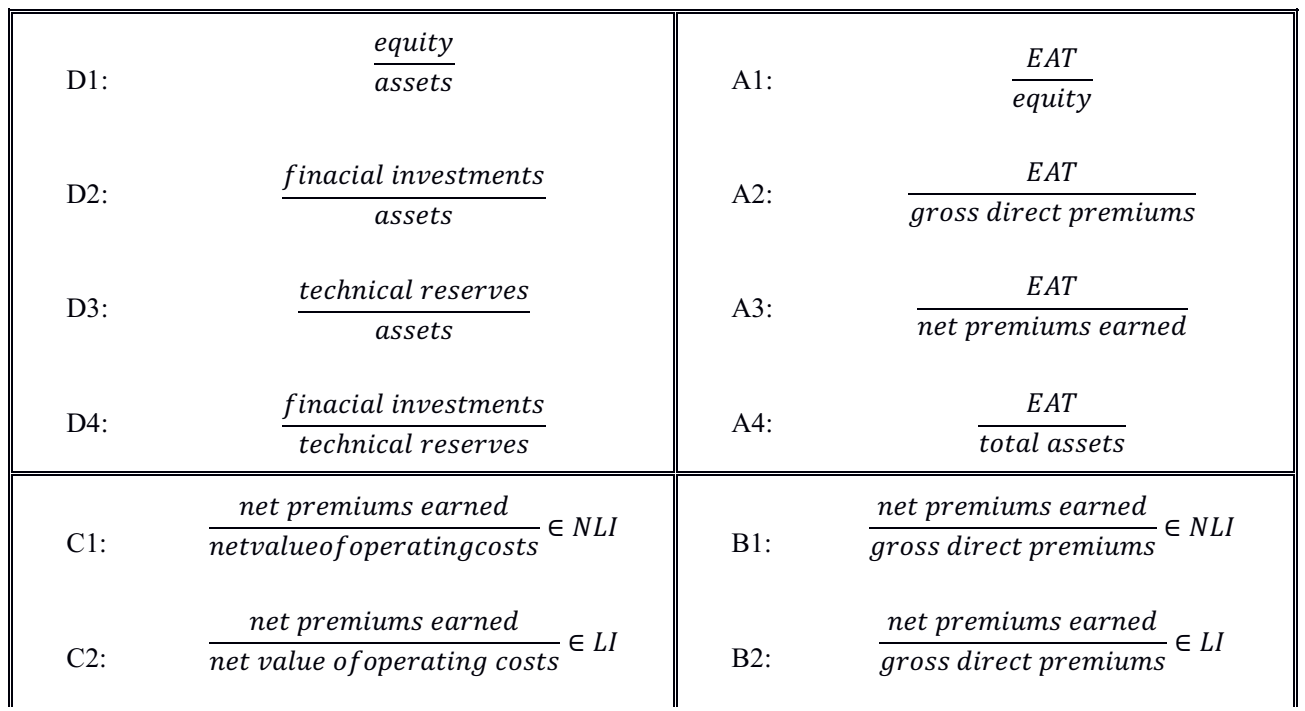




\begin{tabular}{|c|c|c|c|}
\hline C3: & $\frac{\text { allocated investment return }}{\text { investment costs }} \in L I$ & B3: & $\frac{\text { net premiums earned }}{\text { claims incurred }} \in N L I$ \\
\hline C4: & $\frac{\text { allocated investment return }}{\text { investment costs }} \in N L I$ & B4: & $\frac{\text { net premiums earned }}{\text { claims incurred }} \in L I$ \\
\hline
\end{tabular}

Note: LI - life insurance, NLI - non-life insurance

The ratios listed above express the relationship to the market average in percentages, with their number able to change according to the specifications of the sector in which the company is engaged. The ratio relationship that is later entered into the spider graph is calculated according to the following equation:

$$
\text { Spider analysis }=\frac{\text { the value of the examined company's ratio }}{\text { the value of the market average }}
$$

Evaluation by spider analysis cannot compare values over time because the analysis results are evaluated for the individual years being examined.

\section{Evaluating the Insurance Market in the Czech Republic}

The number of insurance companies in the Czech Republic had constantly been increasing up until 2017. In 2000, there were 41 insurers on the Czech insurance market; in 2015, the number of insurance companies even reached a total of 55. In 2017, the number of commercial insurers began to drop to its current number of 47 on account of certain firms closing down and others merging. The current domestic insurance market is comprised of insurers that have received licenses from the Czech National Bank to engage in insurance activities on the basis of having fulfilled demanding criteria. Basic milestones in the development of the Czech insurance market are discussed in [16], [17Chyba! Nenašiel sa žiaden zdroj odkazov.], [18Chyba! Nenašiel sa žiaden zdroj odkazov.], [19] and [20].

Commercial insurance companies attempt to persuade potential clients to enter into insurance contracts in a highly competitive environment. During the period of 2014 to 2016, there was nearly constant year-on-year growth of 500,000 new insurance contracts, with the number of insurance contracts increasing from 26.5 million to 27.5 million between 2014 and 2016. In 2017, the number of insurance policies even increased by 800,000 new policies in comparison to the previous year, which is a year-on-year rate of $3 \%$. The same as for other companies, achieving profit is one of the goals of commercial insurance companies [21]. During this period, the insurance market reported positive numbers from 2014 to 2017. In 2014, commercial insurers had positive operating results of CZK 12 billion, and insurance carriers improved by another CZK 2 billion the following year. Two years of declining operating results followed although insurers ended 2017 with a profit of CZK 10.5 billion. Two years later, 2018 was successful for commercial insurance companies, because their profit rose to nearly CZK 14 billion.

Using each of the ratios listed in Table 1, it is possible to create awareness of how selected commercial insurance companies stand in the given ratio's specialized field of financial analysis, although this does not take into account other areas of financial analysis. The spider graph is composed of four quadrants - A, B, C, and D - and each contains four ratios, which gives an overall number of 16 ratios. See Section 3.1 for more detail. These are expressed in percentages with regards to the insurance market average for the Czech Republic; thus, the insurance market's basic value equals $100 \%$ for each independent ratio. Thus, spider analysis 
not only compares the selected insurers' results with the sector average, but it can also specify the insurance companies' standing in comparison with competitive commercial insurance providers. The amount and composition of the net premiums earned by the overall insurance market for 2014 were unique. Their total sum was CZK 119 billion, the highest for this period of 2014 to 2018, and it was composed of nearly 55\% life insurance policies, with this level gradually decreasing over the next years. Life insurance contributed an even greater percentage, specifically $66 \%$, to the overall sum of paid claims.

Figures 1 and 2 depict the results of Pojišt'ovna VZP, Hasičská vzájemná pojišt'ovna, Kooperativa pojišt'ovna, and the sector average for 2014 to 2018. The spider graph's structure does not allow for comparison of values over time; for this reason, the spider analysis results are evaluated by individual year from 2014 to 2018.

\section{4}

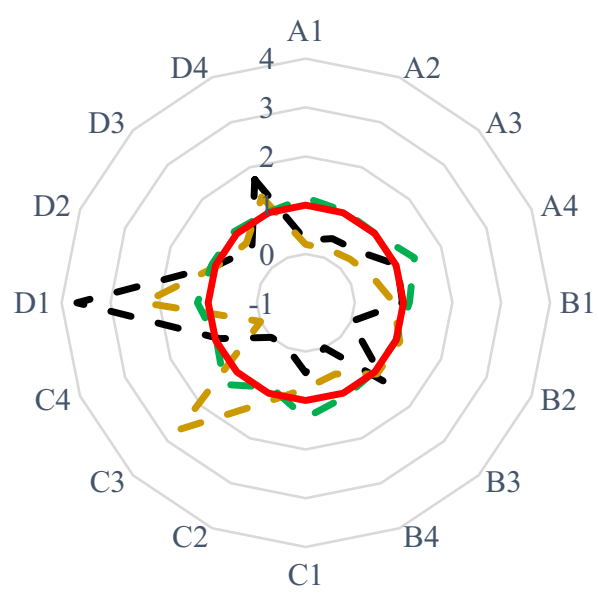

\section{5}

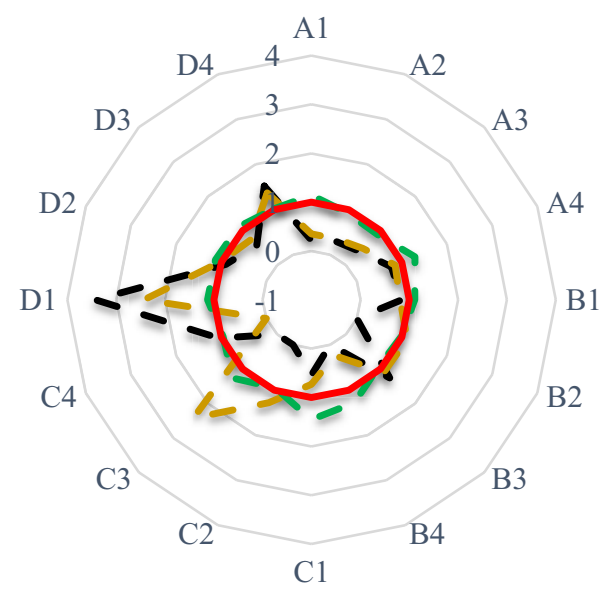

- - PVZP - - HVP - - KOOP Insurance market

Figure 1. Spider analysis results for 2014 and 2015

For evaluating spider analysis, it generally holds only for ratios in quadrant A that the farther away a given insurer's values are compared with the insurance market average, the more effectively they are doing business. For other quadrants - B, C, and D - it cannot be universally said that higher ratio values are a mark of success for commercial insurance companies; rather, it is necessary to evaluate individual ratios separately in conjunction with the variables under investigation. Pojišt'ovna VZP does not provide life insurance, so three ratios from quadrants $\mathrm{B}$ and $\mathrm{C}$ have a value of 0 . The values for the selected ratios showed a similar trend in 2014 and 2015 (Figure 1). 

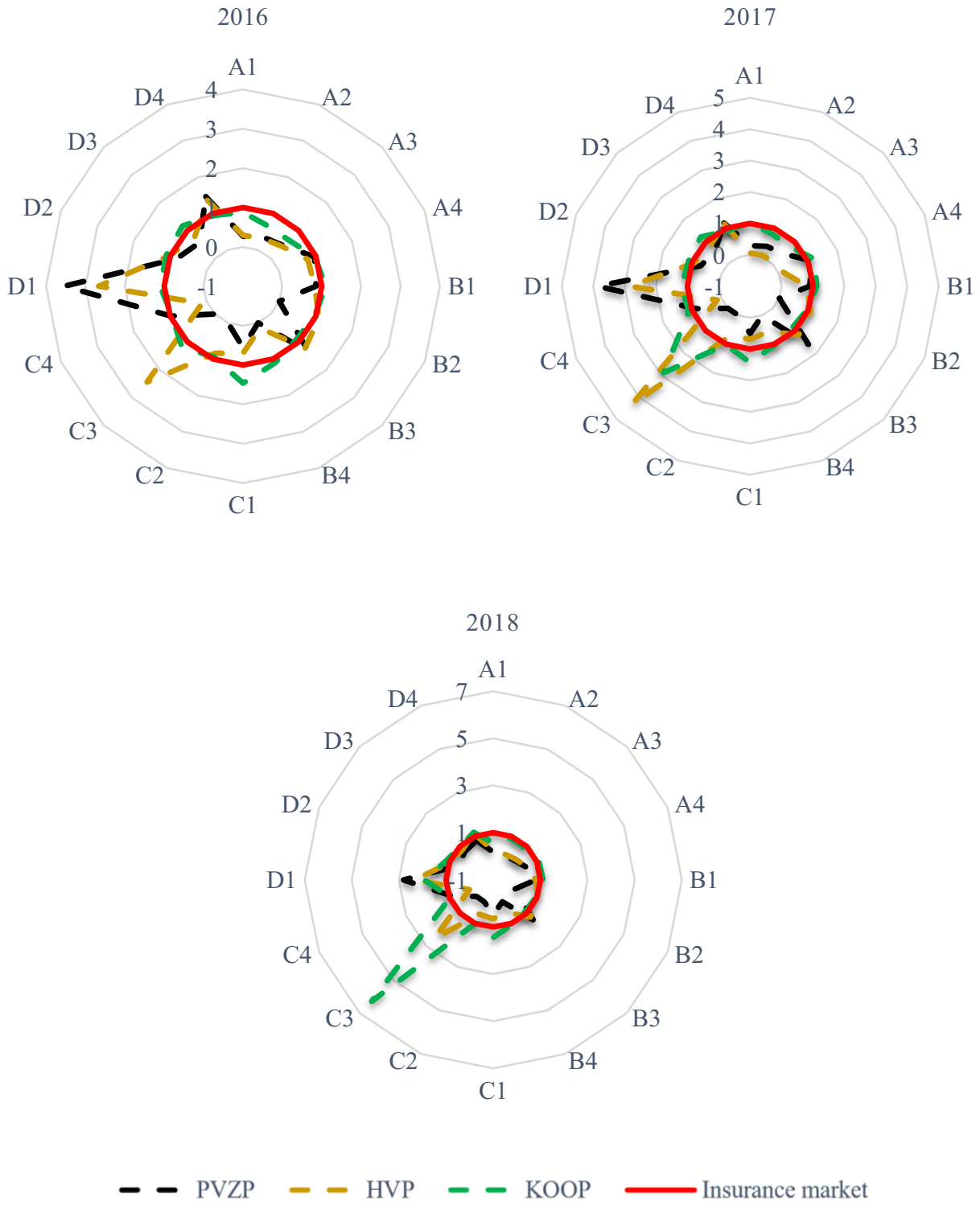

Figure 2. Spider analysis results for 2016 to 2018

For the insurance market, 2016 was important from the perspective of legislative changes because an insurance act was passed to apply the European Solvency II regulation. The year 2017 was not easy for commercial insurers from the financial perspective because of consequences from damage caused by Cyclone Herwart. Concerning the scope of damage across the Czech Republic, this destructive storm caused an 11\% drop in operating results and $8 \%$ growth in costs for non-life insurance claims, whose overall amount topped CZK 37 billion. For insurance companies, 2018 meant a significant modification of information systems in order to fulfill legal requirements for protecting clients' personal privacy. This year, the insurance market prospered both from the perspective of reported profit, which increased by CZK 3 billion to more than CZK 13 billion, as well as from the perspective of 
premiums, which for the first time, amounted to CZK 150 billion during the period of 2014 to 2018 .

\section{Discussion of the Results}

The spider analysis results for Pojišt'ovna VZP, Hasičská vzájemná pojišt'ovna, Kooperativa pojišt'ovna, and the sector average for 2014 to 2018 were used to create a comprehensive picture of their business activity (Figures 1 and 2). Quadrant A is the one quadrant in which higher values represent more effective activity results for all ratios; in all years, this was dominated by Kooperativa pojišt'ovna, the representative of the strongest market entities. The other two insurance companies analyzed were significantly smaller and markedly lagged behind this dominating insurance carrier; each year, they alternated for the second position. For both Pojišt'ovna VZP and Kooperativa pojišt'ovna, their overall premiums typically grew continuously in quadrants $\mathrm{B}$ and $\mathrm{C}$, which strengthened both insurers' positions on the insurance market. Increasing client interest in non-life insurance combined with less than favorable weather conditions forced both insurers to keep investing ever greater financial resources into compensating incurred damage within non-life insurance. The entire time, Pojišt'ovna VZP was actively engaged in investing funds into their non-technical account in indicator C4 - and mostly during the last two years, 2017 and 2018, it was able to prove how much their investment activities gained in importance alongside their role in insurance. Otherwise, Pojišt'ovna VZP lagged behind its competitors the entire time in ratio $\mathrm{C} 1$, which points to it having operating costs in the area of non-life insurance that are too high. With clearly the highest values for D1, Pojišt'ovna VZP proved that it finances its assets predominantly using its own resources; in all years, this distinguished it from other commercial insurance companies, which were not afraid to use foreign capital to a greater degree.

\section{Conclusion}

The growing popularity of insurance was a typical feature of the Czech insurance market for the years 2014 to 2018, as proved by the increasing number of active insurance contracts. Clients showed greater interest in insurance products in the area of non-life insurance, which has driven the Czech insurance market since 2015 and regularly shows higher written premiums than life insurance.

The Czech Republic has undergone a distinct socio-economic transformation, which has affected all areas of the economy. Local changes are derived from the global economy, which has undergone key shifts in the last decades. The predominance of supply over demand was a factor that led to changes that triggered globalization processes. The changes due to globalization are substantial and very universal; they have therefore affected all markets and fields of business, including the insurance industry. Naturally, even the field of insurance has been evolving in conjunction with new technologies and other factors. Digitalizing services have already had a marked effect on the insurance industry, which can be proved by the shrinking number of employees in this field. In conclusion, it can be said that globalization's impact on trends in commercial insurance companies' business activities and in the insurance industry is and will continue to be enormous - as well as difficult to predict in terms of future scope. Currently, the situation linked to COVID-19 has markedly shifted insurance companies' ability to work in the digital world, which will undoubtedly be reflected in the behavior of commercial insurers' financial ratios in the Czech Republic and even the world.

This research was supported by the Czech Science Foundation (Project No. GA 20-00178S) and by the Student Grant Competition of the University of Pardubice SGS_2020_014. 


\section{References}

1. O'rourke, K.H., Williamson, J.G. (2002). When did globalisation begin? European Review of Economic History, 6(1), 23-50.

2. Olasehinde-Williams, G., Balcilar, M. (2020). Examining the Effect of Globalization on Insurance Activities in Large Emerging Market Economies. Research in International Business and Finance, 53, 101228.

3. Egware, L.E. (1998). Institutional agents of globalization. CBN Economic and Financial Review, 36(4), 352.

4. Northrup, D. (2009). Globalization in Historical Perspective. World System History, 1, 196-211.

5. Friedman, T.L. (2005). The earth is flat: A brief history of the 21st century. New York: Ferrar, Staus and Giroux.

6. Friedman, T.L. (2000). The lexus and the olive tree. Challenge-New York, 43(1), 125 129.

7. Pearson, R. (1997). Towards a historical model of services innovation: The case of the insurance industry, 1700-1914. The Economic History Review, 50(2), 235-256.

8. Schiro, J.J. (2006). External forces impacting the insurance industry: Threats from regulation. The Geneva Papers on Risk and Insurance-Issues and Practice, 31(1), 25 30 .

9. Burca, A. M., Batrinca, G. (2014). The determinants of financial performance in the Romanian insurance market. International Journal of Academic Research in Accounting, Finance and Management Sciences, 4(1), 299-308.

10. Nissim, D. (2010). Analysis and valuation of insurance companies. CE| ASA (Center for Excellence in Accounting and Security Analysis) Industry Study Number Two. Columbia Business School

11. Horváthová, Z., Čajková, A. (2019). Framework of the sickness insurance in the Czech Republic and selected countries of the European Union. European Journal of Transformation Studies, 7(1), 106-125.

12. Malik, H. (2011). Determinants of insurance companies profitability: An analysis of insurance sector of Pakistan. Academic Research International, 1(3), 315-321.

13. Vojinović, Ž., Milutinović, S., Leković, B. (2020). Micro-specific profitability factors of the Serbian insurance industry: a panel data estimation. E+M Economics and Management, 23(1), 135-155.

14. MagnusWeb (2020, January 1). Komplexní informace o firmách v ČR a SR. Bisnode Česká republika, a.s. Retrieved from: https://magnusweb.bisnode.cz/

15. Lemieux, V. (2013). Financial analysis and risk management: Data governance, analytics and life cycle management. Berlin: Springer.

16. Kopecká, L. (2018). Comparsion of mortality caused by serious diseases with regions of the Czech Republic. Scientific papers of the University of Pardubice. Series D, 26(2), 112-122.

17. Grmanová, E., Pukala, R. (2018). Efficiency of insurance companies in the Czech Republic and Poland. Oeconomia Copernicana, 9(1), 71-85.

18. Nečas, S., Vávrová, E. (2019). Milestones in the Development of the Modern Insurance Market in the Czech Republic. European Financial Systems 2019: Proceedings of 16th Annual International Scientific Conference on European Financial Systems (pp. 385391). Brno: Masaryk University. 
19. Přečková, L., Vávrová, E. (2019). The Expense Ratio Development of Insurance Portfolios in Selected Insurance Companies in the Czech Republic in 2010-2017. European Financial Systems 2019: Proceedings of 16th Annual International Scientific Conference on European Financial Systems (pp. 452-461). Brno: Masaryk University.

20. Arltová, M., Kabrt, T. (2018). Analysis of Determinants, Influencing Life Insurance Demand in the Czech Republic. Politická ekonomie, 66(3), 344-365.

21. Gogola, J. (2017). Quantification of Longevity Risk for Pension Insurance in V4 Countries. Ekonomický časopis, 65(8), 751-762. 